\title{
Parasitoids of Phyllonorycter platani (Staudinger) (Lepidoptera, Gracillariidae) in Serbia
}

\author{
Čedomir Marković (Corresponding author) \\ Faculty of Forestry, Belgrade University \\ Kneza Višeslava 1, Belgrade 11030, Serbia \\ Tel: 381-113-553-122Ｅ-mail: markovicc@ptt.rs
}

\author{
Aleksandar Stojanović \\ Natural History Museum \\ Njegoševa 51, Belgrade 11000, Serbia \\ Tel: 381-113-442-147Ｅ-mail: aleksandar@nhmbeo.org.yu
}

$\begin{array}{lr}\text { Received: September 8, } 2011 & \text { Accepted: October 23, } 2011 \quad \text { Published: March 1, } 2012 \\ \text { doi:10.5539/jps.v1n1p79 } & \text { URL: http://dx.doi.org/10.5539/jps.v1n1p79 }\end{array}$

\begin{abstract}
In the study of parasitoids of the plane leaf miner Phyllonorycter platani during 2004, 18 polyphagous parasitoid species were recorded in four tree rows and four parks in Serbia (3 species of the family Ichneumonidae and 15 species of the family Eulophidae). Among the recorded parasitoids, the most significant were the species Minotetrastichus platanellus, Pediobius saulius and $M$. frontalis, followed by the species Pnigalio agraules, $P$. pectinicornis, Sympiesis gordius and Neochrysocharis formosa. The other parasitoid species were rare and few. The parasitism rates in the study samples of $P h$. platani ranged from 15.0 to $37.8 \%$.
\end{abstract}

Keywords: Parasitism, Parasitoids, Phyllonorycter platani, Platanus acerifolia

\section{Introduction}

Thanks to its high ornamental value, fast growth, resistance to air pollution and dust, European plane (Platanus acerifolia (Ait.) Willd.) is frequent in parks and tree rows in Serbia. Unfortunately, its trees are often severely infested by the leaf miner Phyllonorycter platani. For that reason, the planes loose much of their ornamental value and their premature defoliations are frequent (Marković et al., 2006).

Ph. platani is an invasive species which, in the second half of the $19^{\text {th }}$ century and during the $20^{\text {th }}$ century, spread from the south of the Balkan Peninsula and from western Asia to other parts of Europe, North Africa and central parts of Asia (Šefrová, 2003). In Serbia, it is an allochthonous species which usually develops four overlapping generations per year (Bogavac, 1959). As there is usually no suppression in Serbia, the abundance of its populations in our parks and tree rows is mainly conditioned by the effects of climate factors and its natural enemies.

Natural enemies of Ph. platani in Serbia are still insufficiently known, therefore our research addressed to its parasitoids. As it is a very harmful allochthonous species in Serbia, our interest was focused on: 1. the number and the species of its parasitoids in this environment, 2. the most significant species of its parasitoids, 3. the extent to which the parasitoids affect its abundance. In this aim, the study of its parasitoids was undertaken in 2004. At that time, the following parasitoids were already described in Serbia: Apanteles circumscriptus (Nees) (Braconidae), Cirrospilus elegantissimus Westwood, Sympiesis sericeicornis (Nees), S. gordius (Walker), Chlorocytus phryne (Walker), Minotetrastichus frontalis (Nees), M. platanellus (Mercet) (Eulophidae). However, as the investigations carried out by Bogavac (1959) covered only a small area in Serbia (Belgrade and its surroundings) where the above parasitoid species were found, and as only the names of the recorded parasitoid species were reported in the results, without the analysis of their significance, we decided to investigate the $P h$. platani parasitoids in Serbia in more detail. Ph. platani parasitoids have been reported by several authors to date (Schimitschek, 1939; Ferrière, 1952; Bouček, 1959; Bouček \& Askew 1968; Graham, 1969; Herting, 1975; Van 
Frankenhuyzen, 1983; Vidal \& Buszko 1990). The most detailed research has been performed in Germany (Mey, 1991), England (Godfray et al., 1995), Bulgaria and Switzerland (Girardoz et al., 2007). According to the results of all the above studies, Ph. platani is a host of about 40 parasitoid species, mainly of the family Eulophidae.

\section{Material and Methods}

\subsection{Ph. platani parasitoid complex}

The parasitoid complex of Ph. platani was studied in 4 tree rows and 4 parks in Serbia. The localities of the

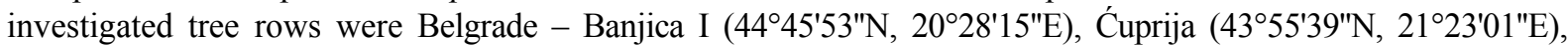
Jagodina $\left(43^{\circ} 58^{\prime} 20^{\prime \prime} \mathrm{N}, 21^{\circ} 16^{\prime} 05^{\prime \prime} \mathrm{E}\right)$ and Paraćin $\left(43^{\circ} 51^{\prime} 59^{\prime \prime} \mathrm{N}, 21^{\circ} 25^{\prime} 00^{\prime \prime} \mathrm{E}\right)$, and the localities of the parks were

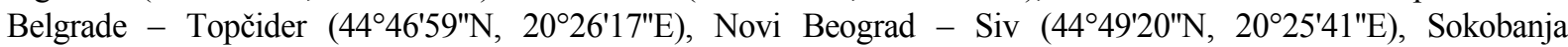

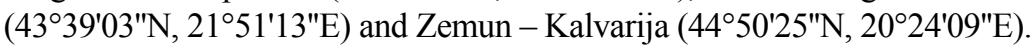

During the appearance of the first adults of the first, second and third Ph. platani generations, in sunny and warm weather, 50 randomly selected leaves with $P h$. platani mines were taken from the lower parts $(\mathrm{h}<3 \mathrm{~m})$ of $P$. acerifolia crowns at the above sites. On being brought into the laboratory, the leaves were placed in emergence boxes, which were kept in the insectarium under field conditions. During the flight of Ph. platani and its parasitoids, the emergence boxes were examined daily. The emerged adults were collected, killed by ether, prepared, identified (by A. Stojanović), and counted. The adults of parasitoids are stored in the collection of the Faculty of Forestry in Belgrade.

A total of 24 samples were collected. The significance of $P h$. platani parasitoids was assessed based on the following:

1). number of localities in which a parasitoid species was identified

2). number of samples in which a parasitoid species was identified; and

3). domination (relation between the number of adults of species of parasitoids and total number of parasitoids, in percentage).

\subsection{Level of parasitism of Ph. platani}

The levels of parasitism of the first, second and third Ph. platani generations were identified in four parks: Belgrade - Banjica II, Belgrade - Topčiderski Park, Novi Beograd - Siv, Zemun - Kalvarija. At these sites, 50 leaves with $P h$. platani mines were randomly selected from $P$. acerifolia trees for each generation. The leaves were taken at the time when the mines were mainly infested with Ph. platani pupae. In the laboratory, 100 to 170 randomly selected leaf mines were opened, and the identified live pupae and larvae were dissected. The maximal number of mines opened per leaf was 5 . The mines with young larvae from the overlapping generations were not opened. Mines of the first, second and third Ph. platani generations from which the butterflies had already emerged at the time of sampling, were included by random selection of the mines for the analysis. In addition, empty mines (attacked by predators) were also randomly selected as well as the mines containing pupae and larvae killed by diseases or unidentified agents.

Ph. platani parasitism rates were calculated by the Girardoz et al. formula (2007): parasitism = number of mines with parasitoids/total number of analysed mines (in percent).

The significance of differences in the parasitism of the first, second and third Ph. platani generations at the study sites were established using Duncan test.

\section{Results}

\subsection{Parasitoid complex of Ph. platani}

Altogether 1054 adult parasitoids of Ph. platani were obtained from the collected P. acerifolia leaf samples. 18 species were determined of which 3 species of the family Ichneumonidae and 15 species of the family Eulophidae (Table 1). Among the obtained parasitoids, the most frequent and most abundant species were Minotetrastichus platanellus, Pediobius saulius and M. frontalis. M. platanellus and P. saulius were dominant parasitoids in the greatest number of samples (M. platanellus $58.3 \%$, P. saulius $20.8 \%$ ). The domination of $M$. platanellus was often rather high $(65-85 \%)$. M. frontalis occurred frequently, but its abundance was usually not high in the samples from which it was obtained. The rates of its domination in them usually did not exceed $20 \%$.

In addition to M. platanellus, $P$. saulius and M. frontalis, Pnigalio agraules, P. pectinicornis and Sympiesis gordius were also somewhat frequent among the identified $P h$. platani parasitoids, but they were abundant only in individual samples (Table 1). Neochrysocharis formosa also occurred frequently, but its abundance was 
always low. Other species of identified parasitoids were rare and few. Consequently, their significance as $P h$. platani parasitoids during the study period was not high.

The dissection of Ph. platani larvae and pupae showed the gregariousness and hyper-parasitism in several samples. As the described parasitoid species (Table 1) were not only primary parasitoids, and as M. platanellus and $M$. frontalis were also gregarious, the calculated values of their dominance were by all means somewhat increased compared to real values, therefore they should be accepted with reservations.

\subsection{Level of parasitism of Ph. platani}

In general, the parasitism level of Ph. platani in the study samples accounted for 15.0 to $37.8 \%$ (Table 2).

The statistical processing of the study data (Table 2) showed that the parasitism rates of the Ph. platani second generation at all sites was statistically significantly higher than the parasitism rates of the first and the third generations and that there were no statistically significant differences in the parasitism of the first and the third generations (Duncan test of significant differences: F- 15.7, P - 0.0012). However, although the parasitism rate of the second generation was higher, the differences in parasitism of the second generation and the other two generations were not really high.

\section{Discussion}

A list of 21 parasitoid species which can be formed based on our results and Bogavac's results (1959) (see Introduction), shows that $P h$. platani has a great number of natural enemies among the parasitoids in Serbia. Its parasitoids are wide polyphagous species (Bogavac, 1964; Bouček, 1977; Bouček \& Askew, 1968; Vidal \& Buszko, 1990; Mey, 1991, 1993; Graham, 1987, 1991; Zverova, 1992) some of which are also recognised as parasitoids of other harmful invasive leaf miners in Serbia (Stojanović \& Marković, 2004, 2005). They also include the species which were observed as Ph. platani parasitoids for the first time during our research (Baryscapus nigroviolaceus, Cirrospilus viticola, Hemiptarsenus unguicellus, Itoplectis maculator, Scambus calobatus and Sympiesis gyorfii) (Ferrière, 1952; Bouček, 1959; Van Frankenhuyzen, 1983; Vidal \& Buszko, 1990; Mey, 1991; Godfray et al., 1995; Girardoz et al., 2007). Some Ph. platani parasitoids identified during our study in Serbia were also identified by the authors of similar studies of Ph. platani parasitoids mainly in Germany (Mey, 1991), England (Godfray et al., 1995) Bulgaria and Switzerland (Girardoz et al., 2007). The most significant $P h$. platani parasitoids reported in the above studies are M. platanellus, P. saulius and $M$. frontalis, which were also determined as the most significant parasitoids of $P h$. platani in our study. In addition, we also identified the following species as significant parasitoids: P. agraules, P. pectinicornis, S. gordius and N. formosa. Other species of identified parasitoids were rare and their number was small.

It is known that parasitoids can have a high impact on the abundance of some leaf miner species (Swan, 1973; Askew \& Shaw, 1979; Van Driesche \& Taub, 1983; Mey, 1991, 1993; Stojanović \& Marković, 2005). Unfortunately, the data on leaf miner parasitism reported in literature are frequently incomparable because of the different methods of parasitism calculation. To avoid this problem, in our study of $P h$. platani parasitism we applied the method used by Girardoz et al. (2007) in their study of Ph. platani parasitoids in Bulgaria and Switzerland. Our study results show that $P h$. platani parasitism in Serbia ranged between 15 and $37.8 \%$ and that there were no great differences in Ph. platani parasitism rates in Serbia, Bulgaria (18 - 28 \%), Switzerland (1 27 \%) (Girardoz et al., 2007) and England (35\%) (Godfray et al., 1995).

Compared to some Phyllonorycter species, the study rates of Ph. platani parasitism in Serbia (Table 2) were not high. For example, parasitism rate of the species Ph. robiniella (Clemens) in Serbia was usually above $50 \%$ (Stojanović \& Marković, 2005). On the other hand, the obtained rates of Ph. platani parasitism cannot be considered as low, because they accounted for between 20 and $30 \%$ in the majority of samples. Generally, in the species with such parasitism rates, parasitoids do not exert a decisive influence on the development of the host populations. Probably for that reason, inter alia, the population density of Ph. platani in our parks and tree rows is high at the sites where it is not suppressed.

Along with Ph. platani, other invasive leaf miner species (Dimić et al., 1998; Stojanović \& Marković, 2005; Marković, 2006) have also been introduced to Serbia. Among them, only the species Cameraria ohridella Deschka \& Dimić (Lepidoptera, Gracillariidae) can be compared with Ph. platani by its significance to our parks and tree rows. This horse-chestnut (Aesculus hippocastanum Linnaeus) leaf miner, just like Ph. platani in Serbia (Freise et al., 2002; Stojanović \& Marković, 2004), and also in other parts of Europe (Moreth, 2000; Freise et al., 2002; Volter \& Kenis, 2006; Girardoz et al., 2007), has acquired a rich parasitoid fauna. However, compared to Ph. platani, the effect of its parasitoids is significantly lower (parasitism $1-10 \%$ ). 
Taking into account all the above mentioned data, it can be concluded that Ph. platani is an invasive species which has acquired a great number of parasitoids in Serbia. Unfortunately, their impact on its abundance is not very high.

\section{References}

Askew, R.R., \& Shaw, M.R. (1979). Mortality factors affecting the leaf-mining stages of Phyllonorycter (Lepidoptera: Gracillariidae) on oak and birch 1. Analysis of the mortality factors. Zoological Journal of the Linnean Society, 76, 31-49. http://dx.doi.org/10.1111/j.1096-3642.1979.tb01103.x

Bogavac, M. (1959). Platanov miner - Lithocolletis platani Stgr. Zaštita bilja, 51, 51-61.

Bogavac, M. (1964). Uloga entomofagnih insekata parazita u redukciji populacije jabukinog moljca (Hyponomeuta malinellus Zell.). Zaštita bilja, 78, 197-206.

Bouček, Z. (1959). A study of central European Eulophidae, I: Eulophinae (Hymenoptera). Acta Entomologica Musei Nationalis Pragae, 33, 117-169.

Bouček, Z. (1977). A faunistic review of the Yugoslavian Chalcidoidea (Parasitic Hymenoptera). Acta entomologica Jugoslavica, 13 (Suppl.), 1-145.

Bouček, Z., \& Askew R.R. (1968). Index of Palearctic Eulophidae (excl. Tetrastichinae). Index of Entomophagous Insects 3. Paris: Le Francois.

Dimić, N., Mihajlović, Lj., Krnjajić, S., Perić, P., \& Cvetković, M. (1998). Entomofauna of leaf miners on public greenery dendroflora in and around Belgrade. Acta entomologica Serbica, 3, 61-76.

Ferrière, Ch. (1952). Les parasites de "Lithocolletis platani" en Italie. Bollettino dell'Istituto di Entomologia della Università degli Studi di Bologna, 19, 395-404.

Freise, J., Heitland, W., \& Tosevski, I. (2001). Parasitism of the horse-chestnut leaf miner, Cameraria ohridella Deschka \& Dimić (Lep., Gracillaridae), in Serbia and Macedonia. Journal of Pest Sciences, 75, 152-157.

Girardoz, S., Volter, L., Tomov, R., Quicke, D.LJ., \& Kenis, M. (2007). Variations in parasitism in sympatric populations of three invasive leaf miners. Journal of Applied Entomology, 131, 603-612. http://onlinelibrary.wiley.com/doi/10.1111/j.1439-0418.2007.01146.x/pdf

Godfray, H.C.J., Agassiz, D.J.L., Nash, D.R., \& Lawton, J.H. (1995). The recruitment of parasitoid species to two invading herbivores. Journal of Animal Ecology, 64, 393-402. http://dx.doi.org/10.2307/5899

Graham, M.W.R. de V. (1969). The Pteromalidae of north-western Europe (Hymenoptera: Chalcidoidea). Bulletin of the British Museum (Natural History) (Entomology), Supplement 16, 1-908.

Graham, M.W.R. de V. (1987). A Reclassification of the European Tetrastichinae (Hymenoptera, Eulophidae), with a revision of certain genera. Bulletin of the British Museum (Natural History) Entomology Series, 51, 1-392.

Graham, M.W.R. de V. (1991). A Reclassification of the European Tetrastichinae (Hymenoptera: Eulophidae): revision of the remaining genera. Memoirs of the American Entomological Institute, 49, 1-322.

Herting, B. (1975). Lepidoptera, Part 1 (Microlepidoptera). A catalogue of parasites and predators of terrestrial arthropods. Section A. Host or Prey/Enemy. Commonwealth Agricultural Bureaux, Commonwealth Institute of Biological Control, 6, 1-218.

Marković, С̆. (2006). Phyllonorycter leucographella (Zeller 1850) (Lepidoptera, Gracillariidae) miner on the leaf of Pyracantha coccinea Roem. Biljni lekar, 6, 447-450.

Marković, Č., Stojanović, A., \& Marković, M. (2006). Platanov miner Phyllonorycter platani (Staudinger, 1870) (Lepidoptera, Gracillariidae). Biljni lekar, 1, 36-39.

Mey, W. (1991). Über die Bedeutung autochthoner Parasitoidenkomplexe bei der rezenten Arealexpansion von vier Phyllonorycter-Arten in Europa (Insecta, Lepidoptera, Hymenoptera). Mitteilungen aus dem Zoologischen Museum in Berlin, 67, 177-194. http://dx.doi.org/10.1002/mmnz.19910670123

Mey, W. (1993). Zur Parasitierung der Pfennigminiermotte, Leucoptera malifoliella (Costa), (Lep., Lyonetiidae) im Havelländischen Obstbaugebiet. Journal of Applied Entomology, 15, 329-341. http://dx.doi.org/10.1111/j.1439-0418.1993.tb00399.x

Moreth, L., Baur, H., Schönitzer, K., \& Diller, E. (2000). Zum Parasitoid-Komplex der Roßkastanien-Miniermotte in Bayern (Cameraria ohridella, Gracillariidae, Lithocolletinae). Mitteilungen der Deutschen Gesellschaft für Allgemeine und Angewandte Entomologie, 12, 489-492. 
Schimitschek, E. (1939). Beiträge zur Forstentomologie der Türkei. I. Zeitschrift für Angewandte Entomologie, 25, 291-310. http://dx.doi.org/10.1111/j.1439-0418.1939.tb01198.x

Stojanović, A., Marković, Č. (2004). Parasitoid complex of Cameraria ohridella (Lepidoptera: Gracillariidae) in Serbia. Phytoparasitica, 32, 132-140. http://dx.doi.org/10.1007/BF02979778

Stojanović, A., \& Marković, Č. (2005). Parasitoid complex of Phyllonorycter robiniella (Clemens, 1859) (Lepidoptera, Gracillariidae) in Serbia. Journal of Pest Science, 78, 109-114. http://dx.doi.org/10.1007/s10340-004-0077-y

Swan, D. I. (1973). Evaluation of biological control of the oak leaf-miner Phyllonorycter messaniella (Zell.) (Lep., Gracillariidae) in New Zealand. Bulletin of Entomological Research, 63, 49-55. http://dx.doi.org/10.1017/S0007485300050872

Šefrová, H. (2003). Invasions of Lithocolletinae species in Europe - causes, kinds, limits and ecological impact (Lepidoptera, Gracillariidae). Ekologia, 22, 132-142.

Van Driesche, R.G., \& Taub, G. (1983). Impact of parasitoids on Phyllonorycter leafminers infesting apple in Massachusetts. USA Protection Ecology, 5, 303-307.

Van Frankenhuyzen, A. (1983). Phyllonorycter platani (Staudinger, 1870) (Lep.: Gracillariidae), een bladmineerder op Plataan in Nederland. Entomologische Berichten, 43, 19-25.

Vidal, S., \& Buszko, J. (1990). Studies on the mining Lepidoptera of Poland. VIII, Chalcidoid wasps reared from mining Lepidoptera (Hymenoptera, Chalcidoidea). Polskie Pismo Entomologiczne, 60, 73-103.

Volter, L., \& Kenis, M. (2006). Parasitoid complex and parasitism rates of the horse chestnut leafminer, Cameraria ohridella (Lepidoptera: Gracillariidae) in the Czech Republic, Slovakia and Slovenia. European Journal of Entomology, 103, 365-370. http://www.eje.cz/pdfarticles/1121/eje_103_2_365_Volter.pdf

Zverova M. D. (1992). Entomophages of pests of apple-trees in south-west region of the USSR. Kiev: Nukova dumka.

Table 1. Recorded species of parasitoids and their status and total number of obtained adult parasitoids and their frequency of occurrence at the investigated sites and in the collected samples

\begin{tabular}{|c|c|c|c|c|c|c|}
\hline \multirow{3}{*}{ Species } & \multirow{2}{*}{\multicolumn{2}{|c|}{$\begin{array}{l}\text { Obtained } \\
\text { imagoes }\end{array}$}} & \multicolumn{4}{|c|}{ Frequency } \\
\hline & & & \multicolumn{2}{|c|}{ at the study sites } & \multicolumn{2}{|c|}{ in the study samples } \\
\hline & $\mathrm{n}$ & $\%$ & $\mathrm{n}$ & $\%$ & $\mathrm{n}$ & $\%$ \\
\hline \multicolumn{7}{|l|}{ Ichneumonidae } \\
\hline Itoplectis alternans (Gravenhorst) & 5 & $\overline{0.5}$ & 3 & 37.5 & 3 & 12,5 \\
\hline Itoplectis maculator (Fabricius) & 8 & $\overline{0.8}$ & 4 & 50.0 & 4 & 16,7 \\
\hline Scambus calobatus (Gravenhorst) & 5 & $\overline{0.5}$ & 2 & 25.0 & 2 & 8,3 \\
\hline \multicolumn{7}{|l|}{ Eulophidae } \\
\hline Baryscapus nigroviolaceus (Nees) & 1 & $\overline{0.1}$ & 1 & 12.5 & 1 & 4,2 \\
\hline Cirrospilus lyncus Walker & 3 & $\overline{0.2}$ & 1 & 12.5 & 1 & 4,2 \\
\hline Cirrospilus talitzkii Bouček & 13 & $\overline{1.3}$ & 4 & 50.0 & 4 & 16,7 \\
\hline Cirrospilus viticola (Rondani) & 1 & $\overline{0.1}$ & 1 & 12.5 & 1 & 4,2 \\
\hline Elachertus inunctus Nees & 1 & $\overline{0.1}$ & 1 & 12.5 & 1 & 4,2 \\
\hline Hemiptarsenus unguicellus (Zetterstedt) & 1 & $\overline{0.1}$ & 1 & 12.5 & 1 & 4,2 \\
\hline Minotetrastichus frontalis (Nees) & 132 & $\overline{12.5}$ & 8 & 100 & 16 & 66,7 \\
\hline Minotetrastichus platanellus (Mercet) & 465 & $\overline{44.1}$ & 8 & 100 & 23 & 95,8 \\
\hline Neochrysocharis formosa (Westwood) & 23 & $\overline{2.2}$ & 7 & 87.5 & 9 & 37,5 \\
\hline Pediobius saulius (Walker) & 224 & $\overline{21.3}$ & 8 & 100 & 22 & 91,7 \\
\hline Pnigalio agraules (Walker) & 82 & $\overline{7.8}$ & 7 & 87.5 & 11 & 45,8 \\
\hline Pnigalio pectinicornis (Linnaeus) & 45 & $\overline{4.3}$ & 6 & 75.0 & 6 & 25,0 \\
\hline Sympiesis gordius (Walker) & 35 & $\overline{3.3}$ & 5 & 62.5 & 9 & 37,5 \\
\hline Sympiesis gyorfii Erdös & 2 & $\overline{0.2}$ & 1 & 12.5 & 1 & 4,2 \\
\hline Sympiesis sericeicornis (Nees) & 8 & $\overline{0.8}$ & 4 & 50.0 & 5 & 20,8 \\
\hline
\end{tabular}


Table 2. Ph. platani parasitism in the first, second and third generations

\begin{tabular}{|c|c|c|c|c|}
\hline \multirow{2}{*}{ Sites } & \multirow{2}{*}{ Generation } & \multirow{2}{*}{ Number of opened mines } & \multicolumn{2}{|c|}{ Mines with parasitoids } \\
\hline & & & $\mathrm{n}$ & $\%$ \\
\hline \multirow[b]{2}{*}{ Beograd - Banjica II } & I & 100 & 15 & 15,0 \\
\hline & II & 154 & 51 & 33,1 \\
\hline \multirow[b]{3}{*}{ Beograd - Topčider } & III & 170 & 38 & 22,4 \\
\hline & $\mathrm{I}$ & 112 & 19 & 17,0 \\
\hline & II & 169 & 50 & 29,6 \\
\hline \multirow[b]{3}{*}{ Novi Beograd -Siv } & III & 134 & 26 & 19,4 \\
\hline & $\mathrm{I}$ & 114 & 31 & 27,2 \\
\hline & II & 135 & 51 & 37,8 \\
\hline \multirow{4}{*}{ Zemun - Kalvarija } & III & 153 & 32 & 20,9 \\
\hline & I & 116 & 24 & 20,7 \\
\hline & II & 102 & 33 & 32,4 \\
\hline & III & 111 & 20 & 18,0 \\
\hline
\end{tabular}

